\title{
Ung jente med psykose, kognitiv svikt og kramper
}

\author{
Psykiatriske symptomer kombinert med nevrologiske forstyrrelser bør \\ alltid vekke mistanke om organisk årsak. Vi beskriver en ung pasient \\ hvor utredningen avslørte en nylig beskrevet tilstand det finnes presis \\ diagnostikk og i mange tilfelle effektiv behandling for. \\ Engelsk oversettelse på www.tidsskriftet.no
}

Se kommentar side 2077

\section{Imer Önder Slettedal*}

Ungdomsavdeling psykisk helse

Senter for psykisk helse - barn og ungdom

Oslo universitetssykehus, Ullevål

\section{Hilde Margrete Dahl}

Inger Sandvig

Barneavdeling for nevrofag

Kvinne- og barneklinikken

Oslo universitetssykehus,

Ullevål og Rikshospitalet

\section{Josep Dalmau}

Department of Neurology,

University of Pennsylvania

Philadelphia, PA

USA

\section{Petter Strømme}

petter.stromme@medisin.uio.no

Barneavdeling for nevrofag

Kvinne- og barneklinikken,

Oslo universitetssykehus, Ullevål

\footnotetext{
* Nåværende adresse:

Avdeling for personlighetspsykiatri

Oslo universitetssykehus, Ullevål
}

En jente i skolealder ble innlagt etter partielle krampeanfall $i$ venstre side av ansiktet og venstre arm, ledsaget av redusert bevissthet. Hun hadde $i$ løpet av de siste tre ukene før innleggelsen fortalt foreldrene at hun følte seg «rar». Foreldrene og skolen hadde observert tiltakende personlighetsog atferdsforandringer $i$ form av svingende humør, engstelse og aggressivitet, urolig søvn med mareritt og ufrivillige vridende bevegelser $i$ hendene og ansiktet. Hun var tidligere frisk, hadde fulgt vanlig vaksinasjonsprogram og hadde normal psykomotorisk utvikling og gode skoleprestasjoner inntil symptomstart.

Atferdsendring hos barn er uspesifikt, men når det ledsages av nevrologiske symptomer slik som fokale kramper, vil man tenke på organiske hjerneforandringer, for eksempel forårsaket av tumor eller encefalitt.
Ved innleggelse fant man postiktal inversjon av venstre plantarrefleks, for øvrig sidelikt tempo og kraft $i$ ekstremitetene. Hun var desorientert, afebril, ikke nakkestiv, og hadde ikke hovne ledd, hud-eller ansiktscytter $3,4 \cdot 10^{9} /\left(14,5-14,0 \cdot 10^{9} / l\right)$, C-reaktivt protein $(C R P)<0,5 \mathrm{mg} / \mathrm{l}<10 \mathrm{mg} / \mathrm{l}), \mathrm{SR} 4$ $\mathrm{mm} / \mathrm{t} /<10 \mathrm{~mm} / \mathrm{t}$ ), $B$-laktat $1,6 \mathrm{mmol} / \mathrm{l} /<2,5$ $\mathrm{mmol} / \mathrm{ll})$, B-glukose $4,4 \mathrm{mmol} / \mathrm{l} \quad(3,5-6,0$ mmol/l) og S-kreatinin $45 \mathrm{mmol} / \mathrm{l}$ (35-60 $\mathrm{mmol} / \mathrm{ll}$. Spinalvæsken viste totalprotein $1,0 \mathrm{~g} / \mathrm{ll}<0,4 \mathrm{~g} / \mathrm{ll}$, leukocytter $88 \cdot 10^{6} / \mathrm{l} \quad<4$ - 106/l), laktat $1,2 \mathrm{mmol} / \mathrm{l}(<2,5 \mathrm{mmol} / \mathrm{ll}$ og glukose 3,5 mmol/l. Spinalglukose-blodglukose-ratio var 0,8 $(>0,67)$. Spinalproteinelektroforese var normal. EEG viste langsom aktivitet og noe epileptisk aktivitet, særlig over høyre hemisfære (fig 1). Magnetisk resonanstomografi (MR) av hjernen og medulla spinalis (med og uten kontrastvæske) viste ingen tumor eller signalforandringer $i$ parenkymet og hjernehinner ved T2-vekting.

Klinisk og EEG-messig hadde jenta encefalitt. Dette ble understøttet av forøket mengde totalprotein og økt antall leukocytter i spinalvæsken. Metabolske sykdommer, nevrodegenerative og immunologiske sykdommer ble også overveiet. Normale verdier av serum- og spinallaktat vil vanligvis utelukke mitokondriesykdommer. Normale glukoseverdier serum og spinalvæske, samt normal spinalglukose-blodglukose-ratio nærmest utelukket medfødt glukosetransportdefekt i blodhjerne-barrieren (GLUT1- defekt). Negativ familieanamnese gjorde Huntingtons sykdom lite aktuelt. Systemisk lupus erythematosus (SLE) kan gi psykiatriske og nevrologiske forstyrrelser, men normal SR og manglende hud-, ledd- eller nyreforandringer gjorde denne diagnosen lite sannsynlig (1). Rasmussens encefalitt ble også vurdert. Det er en immunologisk betinget epileptisk encefalopati med spastisk hemiparese, asymmetriske EEG-forandringer og hemiatrofi av cerebrum utslett. Blodprøver viste totalantall leuko-
(2). Tilstanden debuterer ofte med myoklone krampeanfall, mens de mentale forandringene kommer etter hvert, altså i motsatt rekkefølge av det inntrufne hos vår pasient.

Det ble startet symptomatisk behandling med karbamazepin og klorpromazin. Pasienten var afebril, hadde normalt antall leukocytteriblod og normal CRP, hvilket talte imot bakteriell infeksjon. På grunn av det alvorlige sykdomsbildet ble pasienten allikevel bredt dekket med ceftriakson og ampicillin intravenøst med tanke på Borrelia og Listeria. Det ble også gitt aciklovir, selv om laboratoriedata ikke ga holdepunkter for infeksjon med herpesvirus. Senere mikrobiologiske undersøkelser viste ingen holdepunkter for infeksjon med noen av disse agensene og heller ikke infeksjoner forårsaket av Epstein-Barr-, varicella-, rubellaog rabiesvirus, eller Toxoplasma gondii. Test på antistoffer mot Mycoplasma pneumoniae varikke konklusiv. Variant Creutzfeldt-Jakobs sykdom (VCJD) var lite sannsynlig pga. kort sykehistorie og manglende signalendringer $i$ hjernen ved MR-undersøkelse (3) og spinalvæsken var negativ for 14-3-3-protein. Dette proteinet er en markør for nervecelledestruksjon, særlig ved sporadisk Creutzfeldt-Jakobs sykdom (4). I spinalvæsken var det også normal mengde av gliacellemarkøren GFAP Iglial fibrillary acidic protein) og nervecellemarkørene NFLP (neurofilament protein) og tauprotein, som understøttet at det ikke forelå noen form for aktiv hjernevevsdestruksjon. Cerebral magnetisk resonansspektroskopi (MRS) viste normalt metabolittmønster, noe som også talte imot metabolsk/nevrodegenerativ sykdom (5).

Det skjedde en stadig forverring av pasientens psykiatriske symptomer med angst, utagering og vrangforestillinger til tross for behandling med antipsykotika. Uavhengig av kramper hadde hun raserianfall med selvskading og umotivert latter. Hun hadde global kognitiv svikt, dyspraksi, mutisme, søvnløshet, dystoni og katatoni, og forstyrrelser $i$ det autonome nervesystem i form av dilaterte pupiller og takykardi. Hun fikk svelgevansker med sikling, ble inkontinent for urin og avføring, trengte sondeernæring og var for det meste sengeliggende.

Med slike fremtredende psykiatriske symptomer, kombinert med patologisk funn i EEG og spinalvæske, bør man overveie limbisk encefalitt. Dette er en heterogen tilstand forårsaket av autoimmune faktorer og er ikke sjelden assosiert med malign sykdom 


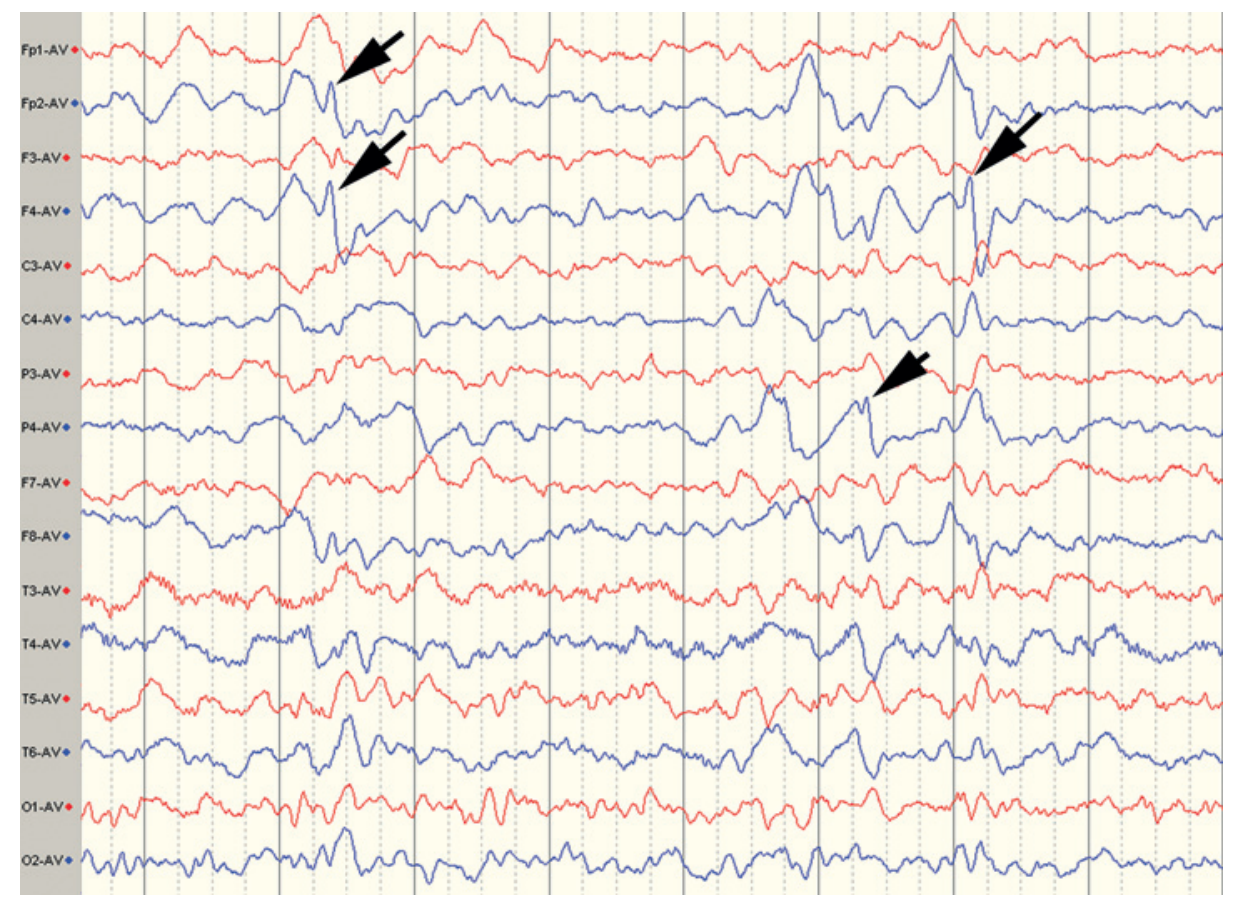

Figur 1 EEG to uker etter innleggelse viser langsom aktivitet, mest uttalt i høyre hemisfære (blå kurve) og enkeltstående epileptiske utladninger (piler) i høyre hemisfære. Pasienten var medisinert med prednisolon, klorpromazin, risperidon, kloralhydrat og karbamazepin. En tidligere undersøkelse uten medikamenter viste samme langsomme rytme, men ikke epileptiforme utladninger

(6). I majoriteten av tilfellene med limbisk encefalitt vil man forvente signalendringer ved T2-vektet MR-undersøkelse, men fravær av dette (som hos vår pasient) utelukker ikke diagnosen.

Vi tolket tilstanden likevel som immunmediert og behandlet med steroider og intravenøs

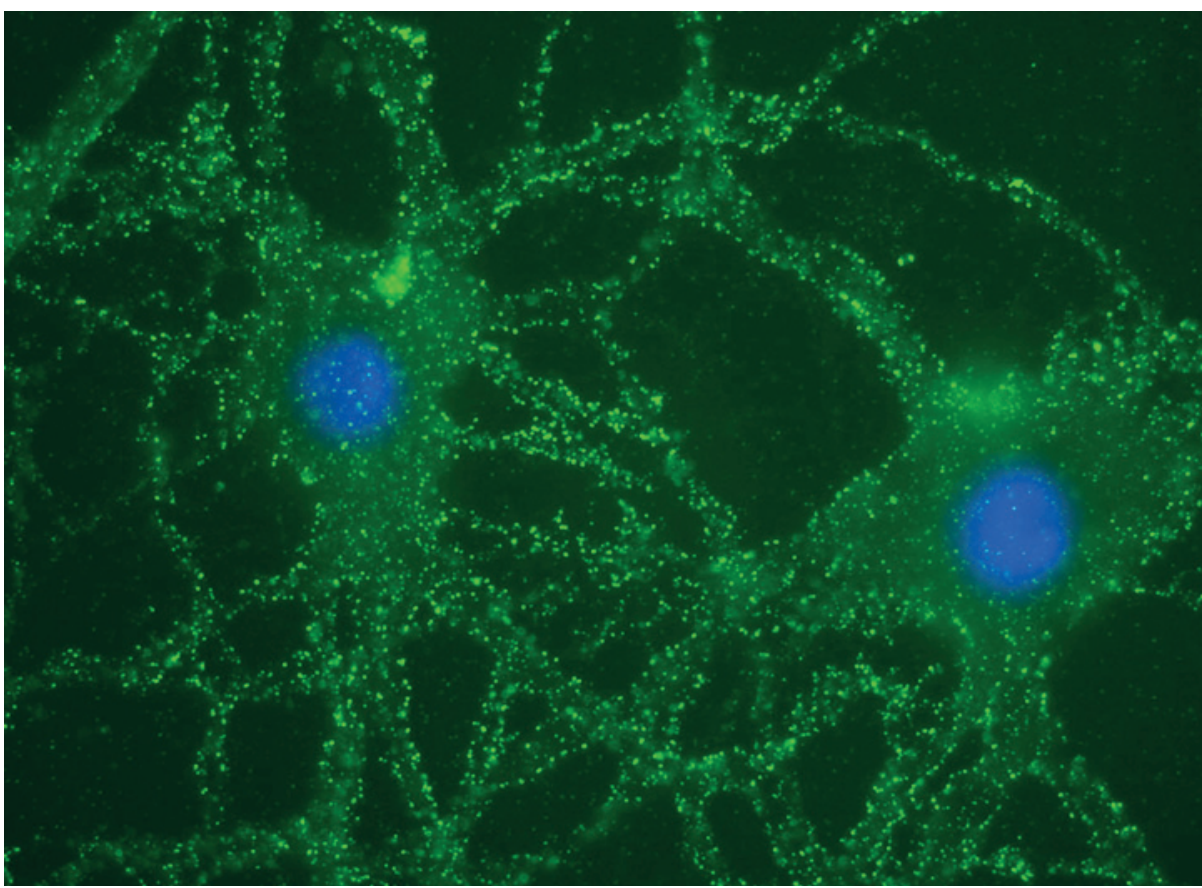

Figur 2 To nevroner i en cellekultur fra rottehippocampus som er immunfarget med spinalvæske fra en pasient. De multiple, intense lysegrønne punktene på celleoverflaten er uttrykk for tilstedeværelse av NMDAreseptorantistoffer. Nervecellekjernene er farget blå med DAPI (4,6-diamidino-2-fenylindol). Figuren er hentet fra Lancaster og medarbeidere (8) og er gjengitt med tillatelse kliniske etterkontroller ble hun undersøkt med tanke på malignitet. Helkropps-CT, MR og positronemisjonstomografi (PET) og abdominale ultralydundersøkelser, samt gjentatte målinger av tumormarkører i serum og urin, var normale. Ved nevropsykologisk undersøkelse 1,5 år etter innleggelse fant man fremdeles svekket kognitiv funksjon. Tilsvarende undersøkelse 2,5 år etter innleggelse viste bedrede resultater og etter 4,5 år helt normale resultater. Hun er i dag frisk.

Den tydelige effekten av plasmautskiftning pekte klart i retning av en immunmediert sykdom, men spesifikke antistoffer eller andre immunologiske markører kunne ikke påvises under sykehusoppholdet. Før behandling med plasmautskiftning ble spinalvæske og serum fra pasienten fryst ned. I lys av rapport om en ny type autoimmun encefalitt (7), ble det nedfryste prøvematerialet senere sendt til University of Pennsylvania, USA. Analysene viste tilstedeværelse av NMDA (N-metyl D-aspartat)-reseptorantistoffer i serum og spinalvæske (fig 2) (8), og vi konkluderte derfor med at diagnosen var anti-NMDA- reseptorencefalitt.

\section{Diskusjon}

Anti-NMDAreseptorencefalitt er ikke helt sjeldent, og i en prospektiv studie av 203 pasienter med encefalitt i England ble det påvist at ni (4\%) hadde NMDA-reseptorantistoffer (9). Så vidt vi kjenner til, er vår pasient den første i Norge som har fått påvist diagnosen anti-NMDA-reseptorencefalitt.

\section{Klinisk bilde}

Anti-NMDA-reseptorencefalitt skiller seg fra limbisk encefalitt ved at den vanligvis utvikler seg trinnvis og gjerne i fem faser: prodromal fase, psykotisk fase, ikke-responsiv fase, hyperkinetisk fase og restitusjonsfase $(10,11)$. Det kliniske bildet ved tilstanden er oppsummert i ramme 1. Majoriteten av pasientene har prodromale symptomer som kan likne en virusinfeksjon. Innen noen dager forekommer det psykiatriske manifestasjoner som angst, nedstemthet, søvnløshet, agitasjon, aggresjon, personlighetsforandringer samt psykotiske symptomer. Tap av korttidshukommelse er vanlig, men kan være vanskelig å påvise hos små barn. Regresjon av språket med ekkolali, ekkopraksi og mutisme oppstår under den ikke-responsive fasen som vanligvis etterfølges av bevegelsesforstyrrelser og katatoni. Instabilitet av det autonome nervesystemet gir temperatur- og blodtrykkssvingninger, sentral hypoventilering, hjertearytmier, svetting, økt spyttproduksjon, inkontinens og obstipasjon. Hos barn er det ofte dystoni eller kramper som fører til sykehusinnleggelse (11). Komplekse partielle eller generaliserte epileptiske anfall kan oppstå når som helst under sykdommen, men fortrinnsvis i tidlige stadier. Status epilepticus kan også forekomme (12). 


\section{Ramme 1}

\author{
Symptomer og tegn \\ ved anti-NMDA-reseptorencefalitt \\ - Prodromale symptomer \\ - kan forveksles med virusinfeksjon \\ - Psykiatriske manifestasjoner \\ - personlighetsendring, angst, \\ agitasjon \\ - søvnforstyrrelse, psykotiske \\ symptomer \\ - Kognitiv svikt og demens \\ - regresjon av språk, \\ hukommelsessvikt \\ - Bevegelsesforstyrrelser \\ - Kramper \\ - Autonome forstyrrelser
}

\section{Patofysiologi}

Den patofysiologiske prosessen der antistoffer blokkerer postsynaptisk glutamaterge eksitatoriske NMDA-reseptorer er illustrert i figur 3 (13). De kliniske stadiene av syndromet oppstår sannsynligvis som følge av økende antistoffmediert svikt i NMDA-reseptorfunksjoner. Den utløsende årsaken til danningen av anti-NMDA-reseptorantistoffer er forbundet med neoplasme i $60 \%$ av tilfellene og resten regnes som idiopatiske (11).
Undersøkelser og diagnose

EEG-mønsteret er nesten alltid patologisk og viser langsom rytme iblandet epileptisk aktivitet (14). Som hos vår pasient (fig 1), kan den endrede rytmen opptre relativt ensidig (15). Patologiske funn i spinalvæsken finnes i flertallet av tilfellene og omfatter moderat økning i antall leukocytter og/eller lett økt totalproteinnivå og av og til oligoklonale bånd (11). MR av sentralnervesystemet viser patologiske endringer hos halvparten av pasientene, og kan ved T2-vektet undersøkelse eller FLAIR (fluid attenuated inversion recovery)undersøkelse vise beskjeden hyperintensitet i temporallappene, lillehjernen, basalgangliene, hjernestammen og av og til i ryggmargen (11). Diagnosen kan bekreftes ved påvisning av spesifikke NMDA-reseptorantistoffer i spinalvæske og serum. (Prøver analyseres ved Nevro-Revma-laboratorium, Haukeland universitetssykehus, Bergen.) Pasientene bør undersøkes med tanke på underliggende tumor. Forekomst av neoplasme øker hos pasienter over 18 år. Hos kvinner er teratom i ovariet den hyppigst assosierte tumor. Relevante undersøkelser for pasienter som mistenkes for anti-NMDA-encefalitt er oppsummert i ramme 2 .

\section{Differensialdiagnoser}

Anti-NMDA-reseptorencefalitt er antakelig den nest vanligste immunmedierte encefalitttypen etter akutt disseminert encefalomyelitt (ADEM), som kjennetegnes av typiske høy-

\section{Ramme 2}

\section{Diagnostisering}

av anti-NMDA-reseptorencefalitt

- Spinalvæske

- noe økt celletall og proteinmengde

- Cerebral MR med T2-vekting

- signaløkning i temporallappene (50\%)

- $\mathrm{EEG}$

- langsom rytme (kan være halvsidig)

- epileptisk aktivitet (ofte sparsom)

- NMDA-reseptorantistoffer bekrefter diagnosen

- påvises i spinalvæske og/eller serum

- Tumor, spesielt teratom (ovarium), bør utelukkes

signalområder i hjernen og ryggmargen ved T2-vekted MR-undersøkelse (16). Det finnes også encefalitter som skyldes antistoffer mot flere andre reseptorer, og ionekanaler, der sykdomsbildet kan overlappe med antiNMDA-reseptorencefalitt (17). En del pasienter med anti-NMDA-reseptorencefalitt $i$ tidlig forløp kommer først til psykiatrisk vurdering og blir behandlet med psykofarmaka (18). Psykofarmaka stopper imidlertid ikke utvikling av sykdommen som kan skride

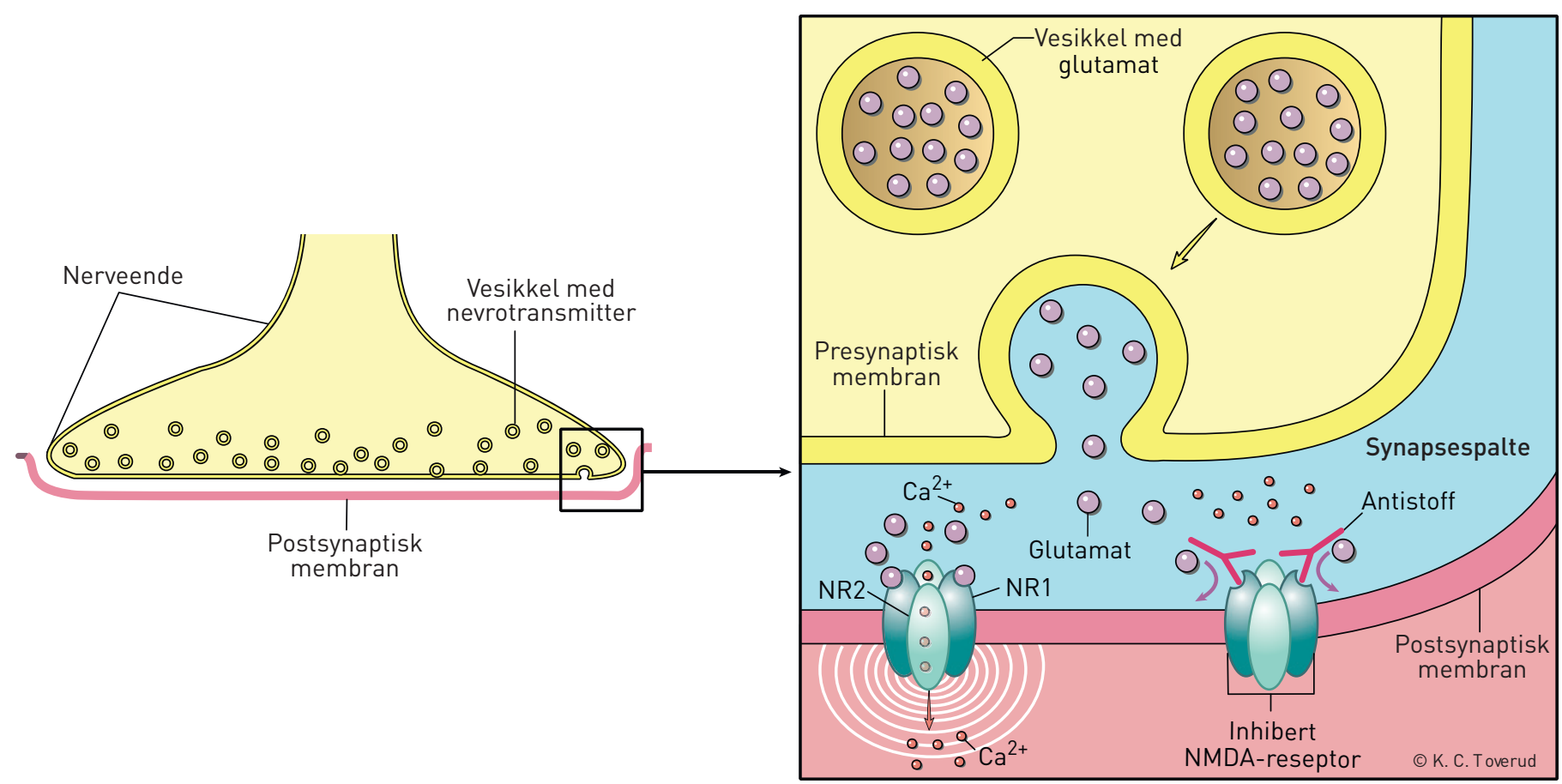

Figur 3 Skjematisk fremstilling av glutamatreseptorer av NMDA (N-metyl D-aspartat)-typen i hjernen. NMDA-reseptoren består av to NR1 og to NR2 underenheter og er viktig for synaptisk «æring» gjennom LTP (long term potentiation). I den forstørrede delfiguren ses normalt fungerende reseptor til venstre og inhibert reseptor til høyre. Nerveimpulser passerer synapsespalten ved at glutamat frigjøres fra presynaptiske vesikler og binder seg til postsynaptiske glutamatreseptorer. NMDA-reseptoren, som også er avhengig av glycin (ikke vist), blir først aktiv når membranen er delvis depolarisert av en annen glutamatreseptor, AMPA-reseptoren (ikke vist), som formidler hovedsignalet. Ca ${ }^{2+}$ slippes normalt gjennom NMDA-reseptoren (reseptor til venstre). Dette setter i gang en intracellulær reguleringskaskade som gjør reseptoren egnet til å modifisere den aktive synapsens signaleringskraft. Antistoffene som forårsaker anti-NMDA-reseptorencefalitt er rettet mot glutamatbindingsstedet på NR1 (reseptor til høyre) 
frem med et sykdomsbilde som til forveksling likner malignt nevroleptikasyndrom med muskelrigiditet, katatoni og autonome forstyrrelser (19). NMDA-reseptorantistoffer ble påvist hos flere som tidligere har fått diagnosen encephalitis lethargica, en tilstand som kjennetegnes av psykiatriske symptomer, søvnvansker, og ekstrapyramidale bevegelsesforstyrrelser (20). Noen barn som tidligere er antatt å ha sent debuterende autisme eller uvanlig tidlige manifestasjoner av schizofreni har vist seg å ha anti-NMDA-reseptorencefalitt (21).

\section{Behandling og prognose}

Behandlingen består i immunterapi med kortikosteroider, intravenøs immunglobulin og/ eller plasmautskiftning $(8,11)$. Ved utilfredsstillende effekt bør rituximab eller cyklofosfamid vurderes. Eventuell tumor bør fjernes. Med denne behandlingsstrategien oppnår ca. $75 \%$ betydelig bedring; de resterende får alvorlige nevrologiske skader eller dør (11). I omtrent $4 \%$ av tilfellene fører sykdommen til død. De vanligste årsakene til dette er hjertearytmi, status epilepticus, tumorprogrediering og komplikasjoner under opphold ved intensivavdeling $(11,14)$. Bedring av symptomene skjer i motsatt rekkefølge av de kliniske fasene i utviklingen av sykdommen. Symptomatisk støttebehandling omfatter antiepileptika og medikasjon for søvnvansker og psykiatriske og autonome symptomer. Anti-NMDA- reseptorencefalitt krever vanligvis mange måneders innleggelse i sykehus etterfulgt av fysisk og kognitiv rehabilitering. Restitusjon kan ta opptil tre år (11). Tidlig og aggressiv behandling er viktig for optima kognitiv funksjon (22). Sosial atferd og eksekutive funksjoner normaliseres sist. Amnesi for sykdomsforløpet er vanlig. Tilbakefall forekommer hos opptil $25 \%$ av pasientene og immunsuppresjon er anbefalt $\mathrm{i}$ ett år etter at initialbehandlingen er avsluttet (11).

\section{Addendum}

Etter at arbeidet med denne artikkelen ble påbegynt, ble en pasient med psykose og katatoni overflyttet barneavdelingen for mistanke om malignt nevroleptikasyndrom. EEG viste uttalt langsom rytme, men ingen epileptisk aktivitet. Analyser i serum og spinalvæske var positive på NMDA-reseptorantistoffer.

Pasienten og pasientens foreldre har gitt samtykke til at artikkelen blir publisert. Pasienten om talt $i$ addendum har også samtykket.
Vi takker Inger Anette Hynås Hovden, Klinisk nevrofysiologisk laboratorium, Oslo universitetssykehus, Ullevål, for tolking av EEG.

\section{Imer Önder Slettedal (f. 1976)}

er lege i spesialisering i barne- og ungdomspsykiatri.

Forfatter har fylt ut ICMJE-skjemaet og oppgir ingen interessekonflikter.

\section{Hilde Margrete Dahl (f. 1966)}

er spesialist i barnesykdommer og overlege med traumatiske hodeskader som spesialfelt. Forfatter har fylt ut ICMJE-skjemaet og oppgir ingen interessekonflikter.

\section{Inger Sandvig (f. 1953)}

er spesialist i barnesykdommer og overlege med epilepsi som spesialfelt.

Forfatter har fylt ut ICMJE-skjemaet og oppgir ingen interessekonflikter.

\section{Josep Dalmau (f. 1953)}

er professor (research professor) ved ICREAIDIBAPS, Hospital Clinic, University of Barcelona, og professor (adjunct professor) i nevrologi ved Department of Neurology, University of Pennsylvania og har nevroimmunologi som spesialfelt.

Forfatter har fylt ut ICMJE-skjemaet og oppgir følgende interessekonflikter: Han mottar royal ties fra Up-To-Date, og fra patenter for benyttelse av Ma2 og NMDA-reseptor i antistoffanalyser. Han har mottatt stipend fra Euroimmun, The National Institute of Health (R01NS077851 og R01MH094741), The National Cancer Institute (R01CA89054), og Fundació la Marató de TV3 og McKnight Neuroscience of Brain Disorders Award.

\section{Petter Strømme (f. 1951)}

er spesialist i barnesykdommer, overlege og professor med nevrodegenerasjon og genetiske årsaker til utviklingshemning som interessefelt. Forfatter har fylt ut ICMJE-skjemaet og oppgir ingen interessekonflikter.

\section{Litteratur}

1. Bader-Meunier B, Armengaud JB, Haddad E et al Initial presentation of childhood-onset systemic lupus erythematosus: a French multicenter study. J Pediatr 2005; 146: 648-53

2. Sandvig I, Tennøe B, Eriksson A-S. En ti år gammel gutt med progredierende nevrologiske utfall. Tidsskr Nor Lægeforen 2006; 126: 779-81.

3. Heath CA, Cooper SA, Murray K et al. Validation of diagnostic criteria for variant Creutzfeldt-Jakob disease. Ann Neurol 2010; 67: 761 - 70.

4. Van Everbroeck B, Boons J, Cras P. Cerebrospinal fluid biomarkers in Creutzfeldt-Jakob disease. Clin Neurol Neurosurg 2005; 107: 355-60.

5. Kanavin $\emptyset \mathrm{J}$, Strømme P. Barn med nevrodegene rativ sykdom. Tidsskr Nor Legeforen 2010; 130 1489-92

6. Storstein A, Bru A, Vedeler CA. Limbisk encefalitt-en diagnostisk utfordring. Tidsskr Nor Lægeforen 2007; 127: 3077-80.

7. Dalmau J, Tüzün E, Wu HY et al. Paraneoplastic anti-N-methyl-D-aspartate receptor encephalitis associated with ovarian teratoma. Ann Neurol 2007; 61: 25-36.

8. Lancaster E, Martinez-Hernandez E, Dalmau J. Encephalitis and antibodies to synaptic and neuronal cell surface proteins. Neurology 2011; 77: 179-89

9. Granerod J, Ambrose HE, Davies NWS et al Causes of encephalitis and differences in their clinical presentations in England: a multicentre population-based prospective study. Lancet Infect Dis 2010; 10: 835-44.

10. lizuka T, Sakai F, Ide T et al. Anti-NMDA receptor encephalitis in Japan: long-term outcome without tumor removal. Neurology 2008; 70: 504-11.

11. Dalmau J, Lancaster E, Martinez-Hernandez E et al. Clinical experience and laboratory investigations in patients with anti-NMDAR encephalitis. Lancet Neurol 2011: 10: 63-74.

12. Bayreuther C, Bourg V, Dellamonica J et al. Complex partial status epilepticus revealing antiNMDA receptor encephalitis. Epileptic Disord 2009; 11: 261-5.

13. Wandinger KP, Saschenbrecker S, Stoecker W et al. Anti-NMDA-receptor encephalitis: a severe, multistage, treatable disorder presenting with psychosis. J Neuroimmunol 2011; 231: 86-91.

14. Dalmau J, Gleichman AJ, Hughes EG et al. AntiNMDA-receptor encephalitis: case series and analysis of the effects of antibodies. Lancet Neurol 2008; 7: 1091-8.

15. Florance NR, Davis RL, Lam C et al. Anti-Nmethyl-D-aspartate receptor (NMDAR) encephalitis in children and adolescents. Ann Neurol 2009. 66: $11-8$

16. Pavone P, Pettoello-Mantovano M, Le Pira A et al. Acute disseminated encephalomyelitis: a longterm prospective study and meta-analysis. Neuropediatrics 2010; 41: 246-55

17. Vincent A, Bien CG, Irani SR et al. Autoantibodies associated with diseases of the CNS: new developments and future challenges. Lancet Neurol 2011; 10: $759-72$

18. Nasky KM, Knittel DR, Manos GH. Psychosis asso ciated with anti-N-methyl-D-aspartate receptor antibodies. CNS Spectr 2008; 13: 699-703.

19. Neuhut R, Lindenmayer JP. Silva R. Neuroleptic malignant syndrome in children and adolescents on atypical antipsychotic medication: a review. J Child Adolesc Psychopharmacol 2009; 19 415-22.

20. Dale RC, Irani SR, Brilot F et al. N-methyl-Daspartate receptor antibodies in pediatric dyskinetic encephalitis lethargica. Ann Neurol 2009; 66 704-9.

21. Creten C, van der Zwaan S, Blankespoor RJ et al. Late onset autism and anti-NMDA-receptor encephalitis. Lancet 2011; 378: 98

22. Finke $\mathrm{C}$, Kopp UA, Prüss $\mathrm{H}$ et al. Cognitive deficits following anti-NMDA receptor encephalitis. J Neurol Neurosurg Psychiatry 2012; 83: 195-8.

Mottatt 29.2. 2012, første revisjon innsendt 10.4 2012, godkjent 21.6. 2012. Medisinsk redaktør Merete Kile Holtermann. 